\title{
DETERMINATION OF HOODED CROW (CORVUS CORONE L.) POPULATION AND METHODS OF CONTROL IN SHEEP FARM AT RAS SEDR, SOUTH SINAI, EGYPT
}

\author{
AHMED, H. A. A.; M. A. ISSA and Y. A. EISA \\ Plant Protection Research Institute, Agric. Res. Cent. Dokki, Giza, Egypt \\ Corresponding author's \\ Email: Hanyphd@gmail.com - mohamedissa011@gmail.com
}

(Manuscript received 16 April 2018)

\begin{abstract}
$\mathrm{T}$ his paper present information on the population density, depredation and control of hooded crow (Corvus corone) in sheep farm at Ras-sedr, South Sinai, Egypt. The population of hooded crow increased through spring and summer seasons with a peak during June with mean 29.5 individuals, while the lowest recorded during January with 9.5 individuals, where's the winter season. The hooded crow attack sheep farms during the whole year, with increasing in attack against lambs than big animals, the highest percentage of damage recorded during June with $4.76 \& 23.29 \%$ in both lambs and big animals respectively. Mechanical and chemical studies are doing to reduce population of crow. Mechanical control represented with fine net is not effective method to catch hooded crow, but chemical control using three pesticides (Methomyl, Zinc phosphide and super caid) gave more effect on crows in the studied area, with highest value during April reducing population by $46.8,53.1$ and $73.3 \%$ respectively.

Key words: Population density, depredation, hooded crow, Egypt, peak, attack, sheep, farms, lambs, mechanical, chemical, control, pesticides.
\end{abstract}

\section{INTRODUCTION}

Hooded crow is common resident and widespread occurrence throughout Egypt in all habitats (Mullié and Meininger 1985; Goodman et al. 1989; Tharwat, 1997; EL-Danasory 2002; Attia 2013). It's an omnivorous bird and is a constant scavenger (Khattab et al., 2002). In Australia Corvus sp. are scavenger feed from a succession of sources (insects, seeds, fruit, birds, mammals and reptiles). Flocks of sheep make a good source of food, mainly in the form of afterbirths, carrion, few healthy lambs and sick animals are finished off by Corvids (Rowley 1969). In Scotland sheep farmers blamed hooded crow for killing young lambs, attacking the eyes of ewes, Crows attacked $48 \%$ of dead lambs found on the hill, but only $8 \%$ of these were alive at the time of the attack, and most of these were in very weak condition due to disease or starvation (Houston 1977).

The population of hooded crow has shown increased growth in Egypt through last years. Its common in all habitats urban, rural, new reclaimed and even desert 
according to the availability of food sources. There's many complaints from farmers of sheep farming that flocks of crow attack lambs and sheep as the ewes are giving birth. The crow is ferociously intelligent and work in teams to take down prey. Sheep have fallen prey to the growing crow population.

So, our objective aimed to estimate the population of hooded crow (Corvus corone) as well as its attack on lambs at sheep farm and reduce its population by various methods.

\section{MATERIALS AND METHODS}

\section{- Study sites:}

The study was conducted in sheep farm from January to December, 2016 at Ras Sedr district, South Sinai Governorate, Egypt. The farm occupies about $20000 \mathrm{~m}^{2}$, and was divided into two sectors ( $1 \& 2$ ) for crow census.

\section{- Census of hooded crow (Corvus corone):}

The study area was inspected four times every month to count the birds. Observation were done twice daily ( $2 \mathrm{~h}$ after sunrise and $2 \mathrm{~h}$ before sunset) avoiding rainy, foggy and windy weather. We used transect line to census birds. In this method, monitoring was performed through an area of ( $40 \mathrm{~m}$ width by $500 \mathrm{~m}$ length) according to Sarkar et al. 2009. A field binocular (10x50) was used to monitor birds. Birds were identified using Collins Bird Guide (Svensson et al. 2009).

\section{- Lambs inspection:}

Attacked Lambs were checked for crow injury. Wounds, extensive bleeding and hemorrhages around the wounded site were found on alive lambs according to (Houston 1978).

\section{Control studies}

\section{Mechanical control:}

Fine net was used in the field which covered 10-meter square. Tree branches nearby experimental area which crow stand on it was cut. The catched birds by net were killed by chloroform inside killing jar. Average number of crow was determined before mechanical control and after 21 days of mechanical control in the same study area.

\section{Chemical control:}

Methomyl (Lannate 90\%) 114 Oxime carbamate suitable powder Systemic with contact \& stomach Insecticide obtained from Dupont Egypt. Five grams methomyl as a toxic compound mixed with one $\mathrm{kg}$ of Chicken intestines after minced.

A. Zinc phosphide acute poison (zinc phosphide $94 \%$ active ingredient), obtained from Kafr El-Zayate for Pesticides \& Chemicals, Egypt. Five grams Zinc phosphide mixed as a toxic compound with one $\mathrm{kg}$ of Chicken intestines. 
B. Super caid (Bromadiolone 0.005\%) 157 Coumarin Anticoagulant Rodenticide readymade bait on wheat grains obtained from Kafr El-Zayate for Pesticides \& Chemicals, Egypt. One kg super caid as a toxic compound mixed with one $\mathrm{kg}$ of Chicken intestines with little oil.

Experimental area divided to three plots every plot about $1000 \mathrm{~m}^{2}$ for each treatment between them about $500 \mathrm{~m}^{2}$. numbers of crows were recorded in labeled places before treatment. Numbers of crows were recorded after one hour in case of methomyl, then after five hours in case of zinc phosphide and after three days in case of super caid. Each treatment was conducted through one week respectively.

\section{- Statistical Analysis:}

The obtained results were statistically analyzed using COSTAT computer programs (2005).

\section{RESULTS AND DISCUSSION}

Hooded crow (Corvus corone) belonging to the order Passeriformes, its widely distributed in Egypt. There are no birds inelegant as crow.

\section{- Census of hooded crow:}

Data illustrated in Table (1) and Fig (1) showed the total number of counted hooded crow birds fluctuated from different months (from Jan.2016 to Dec.2016). The highest value during the whole months was during June with mean (29.5 individuals) while the lowest during January with mean (9.5 individuals).

The highest value recorded after sunrise were 27 individuals during June, while before sunset the highest value recorded 35 individuals during September. On the other hand, the lowest values after sunrise and before sunset were $7 \& 12$ individuals during January, respectively. The population increased before sunset with total number of 298 individual than after sunrise with 220 individuals. May be because deprivation of food all night.

Statistical analyses indicated that, there was significant differences between the population density at different months.

Our result is in agreement with what Khattab (2002) who stated that, average numbers of Hooded crow differ significantly during year months with highly abundance and distribution during the breeding season which reached its peak at February and the average was declined at the non-breading season. The Hooded crow considered as omnivores bird changes their foraging sites following food availability during the year. The distribution and abundance of this bird change through time and some of these changes are linked to specific human activities.

Also, El-Danasory (2006) cleared that the highest number of Hooded crow recorded during sunrise near buildings and trees in May, followed by near orchards, 
field crops and water canals in August, May and July 2003. While during sun-set near orchards in July followed by near building, field crops and water canals in May and July.

Bonnah (2007) revealed that, the number of Hooded crow increased annually during spring followed by autumn and decreased during summer and winter.

Eman (2008) revealed that, Hooded crow Corvus corone cornix numbers was differed according to the type of the study area Qalubia governorate showed highest population from March to August and lowest number during October, while the highest at Sharkia Governorate during July and the lowest in November. At Ismailia Governorate two peaks were recorded during June \& November, while the lowest during February \& October. Also, she cleared that the population of Hooded crow was higher during summer season.

Table 1. Population of hooded crow (Corvus corone) at sheep farm during 2016.

\begin{tabular}{|c|c|c|c|c|}
\hline \multirow{2}{*}{ Months } & \multicolumn{2}{|c|}{ Observation time } & \multirow{2}{*}{ Total } & \multirow{2}{*}{ Mean } \\
\hline & After sunrise & Before sunset & & \\
\hline Jan 2016 & $7^{f}$ & $12^{f}$ & 19 & $9.5^{c}$ \\
\hline Feb & 11 def & 15 ef & 26 & $13^{b c}$ \\
\hline Mar & 9 ef & $13^{f}$ & 22 & $11^{\mathrm{bc}}$ \\
\hline Apr & $20 \mathrm{abc}$ & 23 de & 43 & $21.5^{\mathrm{ab}}$ \\
\hline May & $25^{a b}$ & 28 abcd & 53 & $26.5^{a}$ \\
\hline Jun & $27^{a}$ & $32 a b c$ & 59 & $29.5^{a}$ \\
\hline Jul & $21^{a b c}$ & $24^{\mathrm{cd}}$ & 45 & $22.5^{a b}$ \\
\hline Aug & $18^{\mathrm{bcd}}$ & 27 abcd & 45 & $22.5^{a b}$ \\
\hline Sep & $23 a b c$ & $35^{a}$ & 58 & $29^{a}$ \\
\hline Oct & $16^{\text {cde }}$ & $26^{\mathrm{bcd}}$ & 42 & $21 \mathrm{abc}$ \\
\hline Nov & $19^{\mathrm{bc}}$ & $34^{a b}$ & 53 & $26.5^{a}$ \\
\hline Dec 2016 & 24 ab & 29 abcd & 53 & $26.5^{\mathrm{a}}$ \\
\hline Total & 220 & 298 & 518 & 254 \\
\hline LSD 0.05 & $7.70 * *$ & $8.15^{* *}$ & --- & $11.63 *$ \\
\hline
\end{tabular}


Fig. 1. Population of hooded crow (Corvus corone) at sheep farm during 2016.

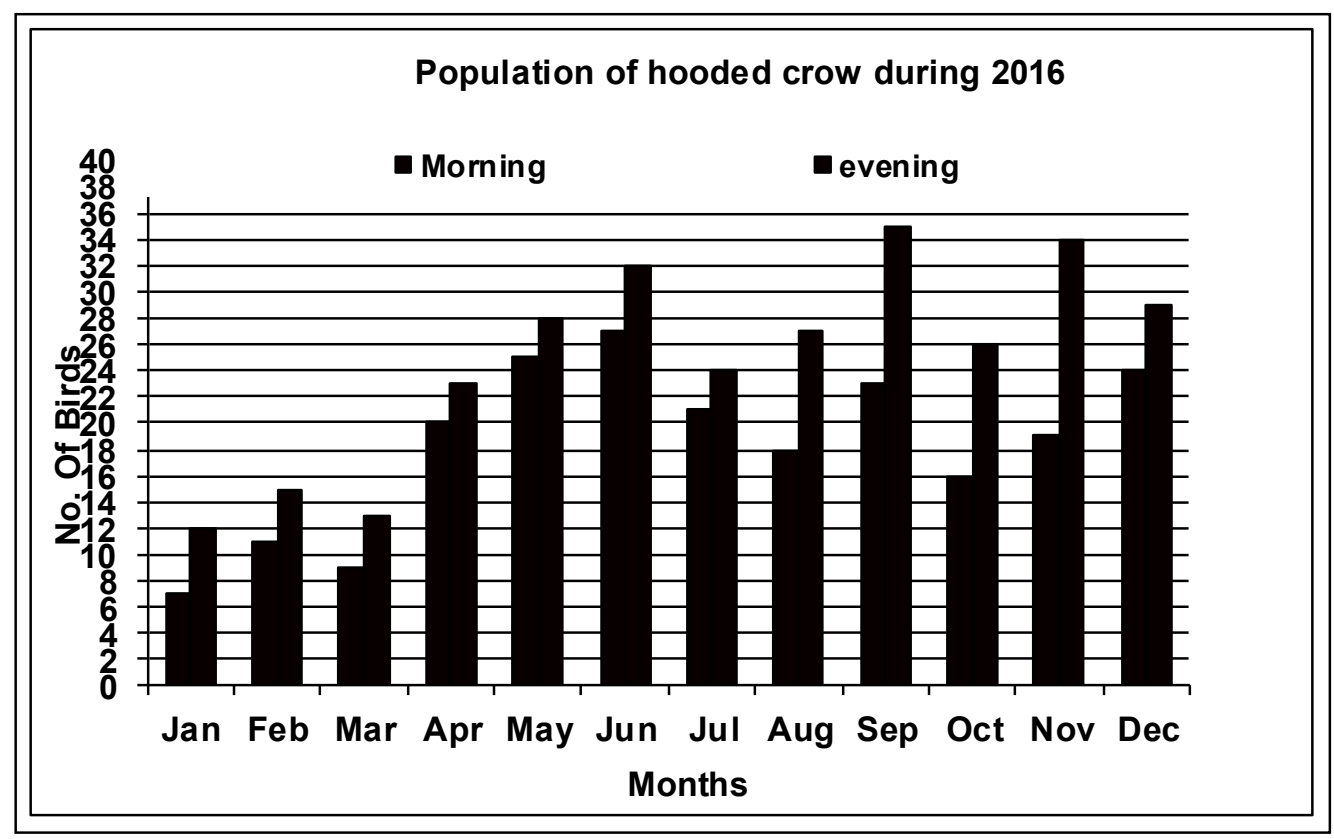

\section{- Lambs inspection:}

observations in the study area showed that's the crow attack head, eyes and tongue these were usually damaged or removed from lambs.

Data in Table (2) and Fig (2) demonstrated that the highest percentage of crow attack against small lambs recorded during June, May, August and July with values of $23.29,13.93,13.22$ and $13.13 \%$, respectively. In the same trend but with a little difference the highly percentage of attacked of biggest animal recorded during June, May, July, April and August with value 4.76, 2.85, 2.62, 2.15 and 1.85\%, respectively. On the other side the lowest percentage of damage in animal recorded during March, in both biggest and small animals, with value 0 and $1.65 \%$, respectively.

Our result agrees with Eman (2013) she mentioned that crows take smaller animals as food and even creature that are already dead. Also, it feed on them and kill for food for their survival. Houston (1978) who cleared that's only $8 \%$ of lambs attacked by crow were alive at the time of the attack, and most of these were in very weak condition due to disease or starvation

But Houston (1977) stated that, during lambing the alternative food supplies for crows as cattle food and insects which are very abundant. Also, in breeding season they feed nestling exclusively on insect. So, he suggests that the attacks are a consequence of the normal predatory behavior.

Also, Rowley (1969) observed that the crow pecked sleeping lamb or recently born hard at the breech. For twin births lambs, during second lamb born the first was unprotected for a time and that's the time where crow attacks. Also, afterbirth 
membranes droopy from the vulva of ewe until cleaning so raven attack the pensile membranes. In addition, that crow try to feed on the first faeces of lambs which adhere to the breech and contains $21-44 \%$ protein so the raven probed the anal of lambs.

Table 2. Total number of sheep and attacked animals during 2016.

\begin{tabular}{|c|c|c|c|c|c|c|}
\hline \multirow{2}{*}{ Months } & \multicolumn{2}{|c|}{ Total No. of animals } & \multicolumn{2}{c|}{$\begin{array}{c}\text { No. of attacked } \\
\text { animals }\end{array}$} & \multicolumn{2}{c|}{$\%$ attacked animals } \\
\cline { 2 - 7 } & adult & small & adult & Small & adult & small \\
\hline Jan 2016 & 418 & 143 & 2 & 6 & 0.47 & 4.19 \\
\hline Feb & 435 & 126 & 1 & 3 & 0.22 & 2.38 \\
\hline Mar & 432 & 121 & 0 & 2 & 0 & 1.65 \\
\hline Apr & 417 & 152 & 9 & 5 & 2.15 & 3.28 \\
\hline May & 420 & 165 & 12 & 23 & 2.85 & 13.93 \\
\hline Jun & 441 & 176 & 21 & 41 & 4.76 & 23.29 \\
\hline Jul & 419 & 137 & 11 & 18 & 2.62 & 13.13 \\
\hline Aug & 403 & 121 & 8 & 16 & 1.98 & 13.22 \\
\hline Sep & 412 & 128 & 5 & 14 & 1.21 & 10.93 \\
\hline Oct & 450 & 96 & 1 & 3 & 0.22 & 3.12 \\
\hline Nov & 441 & 117 & 1 & 4 & 0.22 & 3.41 \\
\hline Dec 2016 & 417 & 134 & 3 & 7 & 0.71 & 5.22 \\
\hline Total & 5105 & 1616 & 74 & 142 & 1.44 & 8.78 \\
\hline
\end{tabular}

Fig. 2. \% attacked lambs by hooded crow (Corvus corone) during 2016.

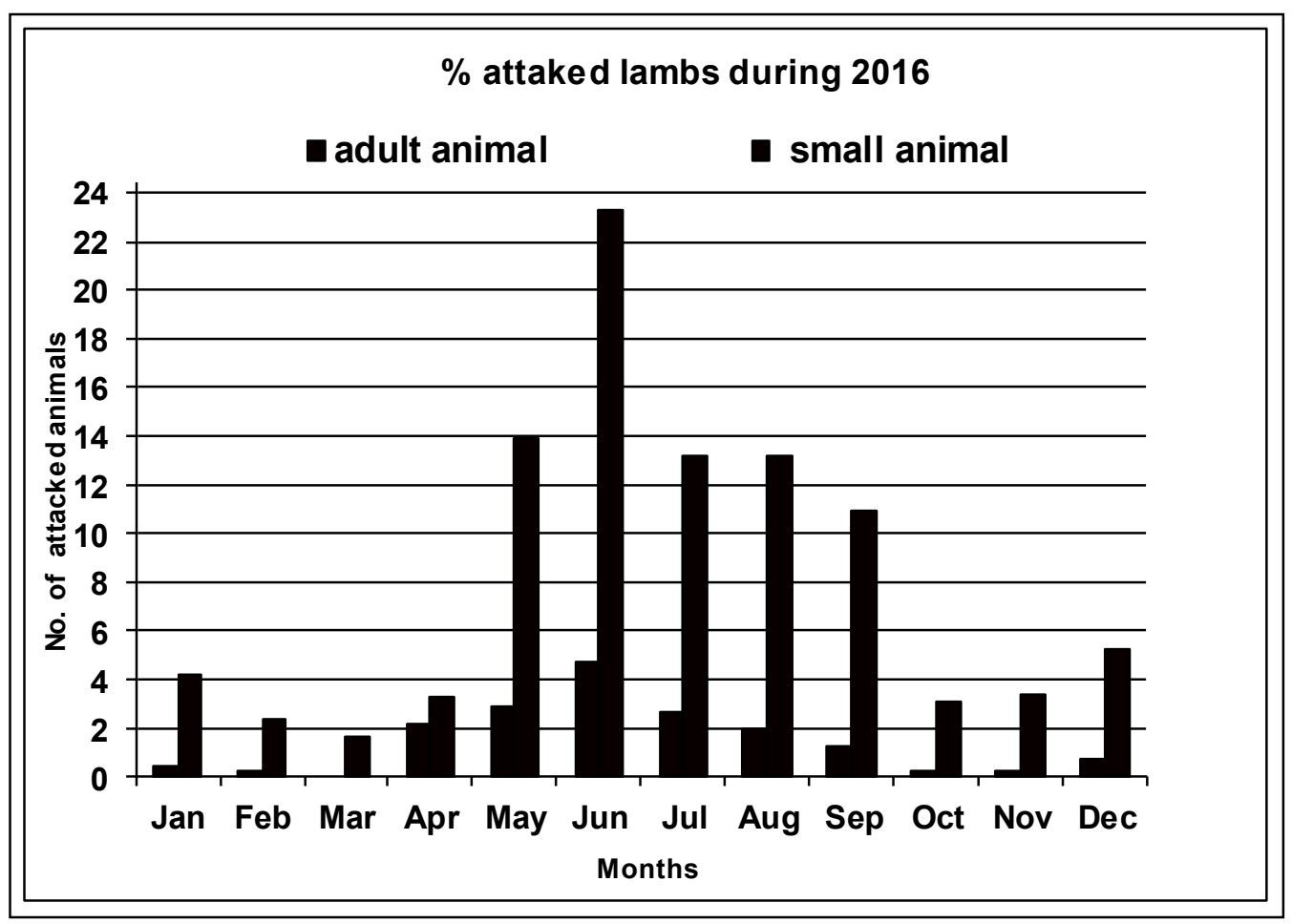




\section{Control studies \\ Mechanical control:}

Fine net is not effective method to catch hooded crow. it catches only one crow during the experiment. Cutting tree branches didn't has any effect on number of crow in hall study area.

\section{Chemical control:}

The results in Table (3) showed clearly, through three months (April, May and June 2017), that the three pesticides (Methomyl) were affective against crow. They reduced crow populations to $46.8 \%$ during April, $40.7 \%$ in May and $31.8 \%$ in June. the effect of Zinc phosphide, as acute poison, were $53.1 \%, 44 \%$ and $38.3 \%$ population reduction. Using super caid (anticoagulant rodenticide) gave the highest effect on crows in the studied area during months reducing population by $73.3 \%$, $73.1 \%$ and $70 \%$ respectively.

Results agree with El-Bahrawy et al. (2007) who cleared that mechanical control of fine net had no effect on brown necked ravens while chemical control using, klerat $(0.005 \%$ brodifacoum) was the most effective against ravens, followed by methomyl and zinc phosphide.

Table 3. Effect of some pesticides on hooded crow number

\begin{tabular}{|l|c|c|c|c|c|c|c|c|c|}
\hline \multirow{3}{*}{ Months } & \multicolumn{9}{|c|}{ Mooded crow numbers } \\
\cline { 2 - 11 } & \multicolumn{3}{|c|}{ Methomayl } & \multicolumn{3}{|c|}{ Zinc phosphide } & \multicolumn{3}{|c|}{ Super caid } \\
\cline { 2 - 10 } & Before & After & $\begin{array}{l}\text { Population } \\
\text { reduction\% }\end{array}$ & Before & After & $\begin{array}{l}\text { Population } \\
\text { reduction\% }\end{array}$ & Before & After & $\begin{array}{l}\text { Population } \\
\text { reduction\% }\end{array}$ \\
\hline April & 47 & 25 & 46.8 & 49 & 23 & 53.1 & 45 & 12 & 73.3 \\
\hline May & 54 & 32 & 40.7 & 50 & 28 & 44.0 & 52 & 14 & 73.1 \\
\hline June & 63 & 43 & 31.8 & 65 & 40 & 38.5 & 60 & 18 & 70.0 \\
\hline
\end{tabular}

\section{CONCLUSION}

In conclusion, our results revealed that whereas the highest density of crow bird there were a highest percentage of attack against sheep farm. Also, the effectiveness of bird control methods differed considerably according to the control methods (Mechanical control \& Chemical control). The chemical control was more effective than mechanical control.

It is recommended to use chemical control as bird baits for alleviating the great damage caused by hooded crow during spring season (March, April and May) to decrease the bird population and prevent bird attacking.

\section{REFERENCES}

1. Attia, M. A. I. 2013. Studies on some wild bird species at Ismailia Governorate. Ph.D. Thesis, Fac. Agric., Al-Azhar Univ, Egypt, 216 pp.

2. Bonnah, A. A. M. M. 2007. The damage by and control of hooded crow on some plantation in Sohag Governorate. Ph.D. Thesis, faculty of Agriculture, Assiut University, Egypt, 116 pp.

3. COSTAT 2005. Version 6.311, copyright (c), Cohort Software, 798 Lighthouse Ave. PMB 320, Monterey CA, 93940, USA. 
4. El -Bahrawy, A. A. F.; Vijver M. G. and G. R. de snoo. 2007. Threats and Control of The Brown Necked Ravens (Corvus ruficollis) in Egypt. Journal of agricultural science. Volume 7 (2), 2007: 21-28.

5. El - Danasory, M. A. 2002. Ecological and biological studies on some harmful birds for plants at Minoufia Governorate. M. SC. Thesis, Fac. of Agric. Al-Azhar Univ.

6. El -Danasory, M. A. 2006. Studies on some wild bird species in Egypt. Ph. D. Thesis Fac. of Agric. Al-Azhar Univ

7. Eman, A. A. A. 2013. Estimation of maize damage caused by Corvus corone sardonius in Sheben Alkom Menofiya governorate. Egypt. Acad. J. Biolog. Sci., 4(2): 11- 17.

8. Eman, H. E. Kh. K. 2008. Environmental problems in relation to Corvidae birds and their management in west and east Delta. M.Sc. Thesis, Inst. Of Enviro. Studies and Res. Ain Shams Univ.

9. Goodman, S. M.; P. L. Meininger; S. M. Bahaa El - Dine; J. J. Hoobs and W. C. Mullie. 1989. The birds of Egypt. Univ. Oxf., New York.

10. Houston, D. 1977. The effect of hooded crows on hill sheep farming in Argyll, Scotland. J Appl. Ecol, 14: 17-29.

11. Houston, D. 1978. The motivation for hooded crow (Corvus corone) attacks on young lambs. J Appl. Biology, 88(2): 339-341.

12. Khattab, M. M. 2002. Field study on population fluctuation of Hooded crow, Corvus corone saronius (KleinSchmidt), At Sharkia Governorate. $2^{\text {nd }}$ International Conference, Plant protection Research Institute, Cairo, Egypt.2124December2002. PP.115-120.

13. Mullié, W.C. \& Meininger, P.L. 1985. The decline of birds of prey in Egypt. Pp. 6182 in Newton, I. \& R.D. Chanchellor [Eds.] Conservation Studies on Raptors, Proceedings of the Second World Conference on Birds of Prey, Thessaloniki, 1982. ICBP Technical Publication No. 5, 61-82., ICBP, Cambridge, UK.

14. Rowley, I. 1969. An evaluation of predation by (Crow) on young lambs. CSIRO Wild. Res.14, 153- 179.

15. Sarkar, N.J.; D. Sultana.; M. F. Jaman and M. K. Rahman. 2009. Diversity and population of avifauna of two urban sites in Dhaka, Bangladesh. Ecoprint 16: 1-7.

16. Svensson, L.; P.J. Grant.; K. Mullarney.; D. Zetterstrom and D. Christie. 2009. Collins Bird Guide: The Most Complete Guide to the Birds of Britain and Europe. Second edition. HarperCollins, London. 


\section{تقدير كثافة تعداد الغربان وطرق مكافحتها في مزرعة للأغنام}

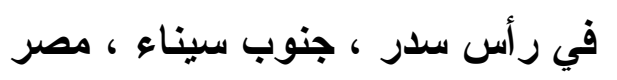

هاتى أحمد عبد العاطى أحمد - محمد عبدالله عيسى - يونس أحمد السيد عيسى

$$
\text { معهر بحوث وقاية النباتات - مركز البحوث الزراعية - الدقي - جيزة - مصر. }
$$

تقدم هذه الدر اسة معلومات عن تعداد الغر اب البلدي وسلوك الافتر اس وكيفية مكافحته فـي

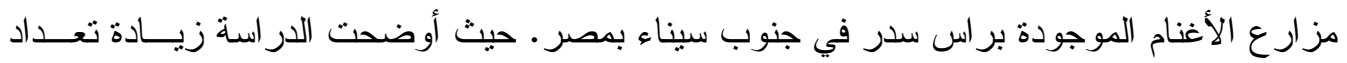

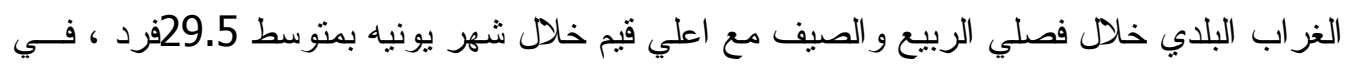
حين أن اقل تعداد سجل خلال شهر يناير بمتوسط 9.5 فرد حيث فصل الثنتاء.

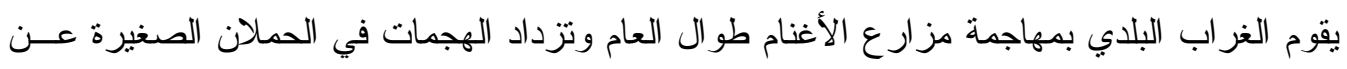
الحيو انات الكبيرة وقد سجل اعلي نسبة خسائر في شهر يونيه بنسبة 4.76 و 23.29 \% لكلا مستن فئن

$$
\text { الحبو انات الصغيرة و الكبيرة علي التو الي. }
$$

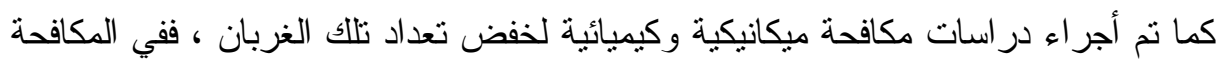

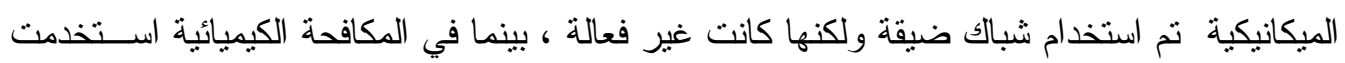

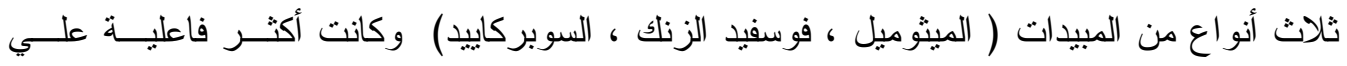

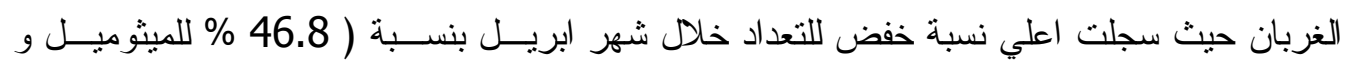
53.1 \% لفوسفيد الزنك و 73.3 \% للسوبر كاييد ). 
